\title{
Pengaruh Model Pembelajaran Learning Cycle 5e Berbantuan Media Lingkungan Terhadap Kompetensi Pengetahuan Ipa
}

\author{
Ni Putu Santika Dewi1* ${ }^{*}$ I Kt Ardana², Made Putra ${ }^{3}$ \\ 1 Jurusan PGSD Universitas Pendidikan Ganesha Singaraja, Indonesia \\ 2 Jurusan PGSD Universitas Pendidikan Ganesha Singaraja, Indonesia \\ ${ }^{3}$ Jurusan PGSD Universitas Pendidikan Ganesha Singaraja, Indonesia
}

\begin{abstract}
Abstrak
Penelitian ini bertujuan untuk mengetahui perbedaan yang signifikan kompetensi pengetahuan IPA kelompok siswa yang dibelajarkan dengan model pembelajaran learning cycle $5 \mathrm{E}$ berbantuan media lingkungan dengan kelompok siswa yang dibelajarkan dengan pembelajaran konvensional pada siswa kelas IV SD Gugus Letkol Wisnu Kecamatan Denpasar Utara tahun ajaran 2017/2018. Desain penelitian ini adalah Penelitian Eksperimen semu dengan rancangan nonequivalent control group design. Populasi penelitian ini adalah seluruh siswa kelas IV SD Gugus Letkol Wisnu Kecamatan Denpasar Utara yang berjumlah 332 orang yang tersebar dalam 9 kelas. Penentuan sampel dilakukan dengan teknik random sampling. Sampel dalam penelitian ini adalah siswa kelas IV A SDN 1 Peguyangan dengan jumlah 43 siswa sebagai kelompok eksperimen dan siswa kelas IV SDN 12 Peguyangan dengan jumlah 41 siswa sebagai kelompok kontrol. Pengumpulan data dilakukan dengan menggunakan metode tes dalam bentuk tes objektif pilihan ganda biasa. Data yang diperoleh dianalisis menggunakan uji-t. Berdasarkan hasil analisis data diperoleh thitung $=4,453$ sedangkan pada taraf signifikansi $5 \%$ dan $\mathrm{dk}=82$ diperoleh nilai ttabel $=1,989$ sehingga thitung $=4,453>$ ttabel $=1,989$. Berdasarkan kriterian pengujian, maka Ho ditolak. Adapun nilai rata-rata kompetensi pengetahuan IPA pada kelompok yang dibelajarkan dengan model pembelajaran Learning Cycle 5E berbantuan media lingkungan adalah 81,53, sedangkan pada kelompok yang dibelajarkan dengan pembelajaran konvensional adalah 72,82. Berdasarkan hasil tersebut dapat disimpulkan bahwa terdapat pengaruh model pembelajaran Learning Cycle 5E berbantuan media lingkungan terhadap kompetensi pengetahuan IPA siswa kelas IV SD Gugus Letkol Wisnu Kecamatan Denpasar Utara tahun ajaran 2017/2018.
\end{abstract}

Keywords:

Learning Cycle 5E,

lingkungan,

kompetensi

pengetahuan IPA

\section{PENDAHULUAN}

Pendidikan merupakan suatu usaha sadar yang didasari untuk mengembangkan kepribadian dan keterampilan manusia yang berlansung seumur hidup. Kualitas kehidupan bangsa ditentukan oleh faktor pendidikan sebagaimana yang diamanatkan UUD 1945 bahwa pendidikan nasional bertujuan untuk mencerdaskan kehidupan bangsa (Sugiantara, 2013). Menurut Hamalik (2013:3), Berdasarkan pendapat di atas mengenai pendidikan, pendidikan harus diarahkan untuk menghasilkan manusia yang berkualitas, mampu bersaing, memiliki budi pekerti yang luhur dan moral yang baik. Pendidikan sangat erat kaitannya dengan pembelajaran, dalam pendidikan formal proses pembelajaran dilaksanakan di sekolah.

Proses pembelajaran di sekolah dilaksanakan dengan berpedoman pada kurikulum yang berlaku. Menurut Hamalik, (2013:16) kurikulum ialah "Sejumlah mata ajaran yang harus ditempuh dan dipelajari oleh siswa untuk memperoleh sejumlah pengetahuan". Kurikulum pendidikan di Indonesia sudah beberapa kali diadakan perubahan dan perbaikan. Setiap perubahan kurikulum merupakan penyempurnaan dari kurikulum sebelumnya, begitu juga kurikulum 2013 yang merupakan penyempurnaan dari kurikulum tingkat satuan pendidikan (KTSP).

Penerapan kurikulum 2013 pada tingkat sekolah dasar menggunakan tematik integratif, yaitu mengaitkan beberapa mata pelajaran ke dalam sebuah tema. Sebuah tema terdiri dari tiga atau empat subtema, dalam subtema tersebut terdiri dari enam pembelajaran. Mata pelajaran seperti Bahasa 
Indonesia, PKn, Matematika, IPA, IPS, Penjaskes, dan SBdP dipadukan dalam kegiatan-kegiatan pembelajaran dalam satu tema, sehingga siswa tidak menyadari sedang mempelajari mata pelajaran tertentu. Dengan demikian mereka dapat memahami suatu konsep dengan utuh bukan hanya sebagai pengetahuan tetapi juga dapat diterapkan melalui kegiatan-kegiatan dalam pembelajaran. Dari berbagai mata pelajaran tersebut, IPA merupakan salah satu mata pelajaran yang sering muncul dalam kegiatan pembelajaran karena berhubungan langsung dengan lingkungan siswa.

Kompetensi dapat dikatakan kemampuan yang ada pada diri siswa untuk menunjukkan dan mengaplikasikan keterampilan tersebut di dalam kehidupan sehari-hari. Kompetensi inti mencakup tiga ranah yaitu, ranah kompetensi sikap, ranah kompetensi keterampilan dan ranah kompetensi pengetahuan.

Kompetensi adalah pengetahuan, keterampilan, dan nilai dasar yang merefleksikan dalam kebiasaan berpikir dan bertindak (Kosasih, 2014:13). Dalam UU No. 20 tahun 2003 tentang "Sistem Pendidikan didefinisikan pula bahwa kompetensi (lulusan) merupakan kualifikasi kemampuan lulusan yang mencakup sikap, pengetahuan, dan keterampilan, yang akan menjadi acuan bagi pengembangan kurikulum dalam rangka mewujudkan tujuan pendidikan Nasional".

Kompetensi pengetahuan merupakan salah satu kompetensi yang tercantum dalam KI-3 Kurikulum 2013 yang merupakan suatu perubahan perilaku seseorang yang dapat dilihat dari segi kemampuan pengetahuan setelah memperoleh pengalaman belajar. Kompetensi pengetahuan dapat dengan jelas mengukur kemampuan siswa dalam memahami dan menguasai isi dari suatu materi setelah memperoleh pengalaman belajar.

Pada kompetensi pengetahuan sesuai dengan taksonomi Bloom yang telah direvisi oleh Anderson dan Krathwohl (dalam Kokasih, 2014 :21) terdapat dimensi proses kognitif pada jenjang proses berpikir meliputi mengingat, memahami, menerapkan, menganalisis, mengevaluasi, dan mencipta, yang biasanya sering dikenal dengan istilah C-1 sampai C-6.

Keenam tingkatan proses berpikir dalam pengukuran kompetensi pengetahuan berkaitan dengan dimensi pengetahuan. Permendikbud nomor 104 tahun 2014 menyatakan bahwa "dimensi pengetahuan dibedakan atas empat kelompok yaitu faktual, konseptual, prosedural dan metakogniktif". Dimensi pengetahuan pada penelitian ini adalah dimensi pengetahuan faktual dan konseptual karena dimensi pengetahuan yang harus dimiliki oleh siswa sekolah dasar hanya merupakan pengetahuan faktual dan pengetahuan konseptual.

Pada penelitian ini kompetensi pengetahuan yang difokuskan adalah kompetensi pengetahuan IPA. IPA merupakan salah satu mata pelajaran pokok dalam kurikulum pendidikan di Indonesia, termasuk dalam jenjang sekolah dasar. "Ilmu pengetahuan alam merupakan terjemahan kata-kata dalam bahasa Inggris yaitu natural science, artinya ilmu pengetahuan alam (IPA) atau dapat diartikan juga ilmu tentang alam" (Samatowa,2016:3). "Sains atau IPA adalah usaha manusia dalam memahami alam semesta melalui pengamatan yang tepat pada sasaran, serta menggunakan prosedur, dan dijelaskan dengan penalaran sehingga mendapatkan suatu kesimpulan" (Susanto,2013:167).

Berdasarkan pemaparan tersebut, IPA adalah rumpun ilmu yang memiliki karakteristik khusus yaitu mempelajari tentang gejala alam baik berupa kenyataan dan hubungan sebab akibat melalui pengamatan yang tepat serta dijelaskan dengan penalaran sehingga mendapatkan suatu kesimpulan.

Pada permendikbud nomor 57 tahun 2014 dijelaskan bahwa pelaksanaan pembelajaran pada Sekolah Dasar dilakukan dengan menggunakan bentuk pelajaran tematik integratif yang artinya muatan materi dalam mata pelajaran Sekolah Dasar yang diorganisasikan dalam tema-tema. Salah satu mata pelajaran yang diorganisasikan dalam tema - tema adalah IPA sehingga mata pelajaran IPA pada tingkat sekolah dasar berupa muatan materi.

Berdasarkan pemaparan tersebut dapat disimpulkan bahwa kompetensi pengetahuan IPA adalah perubahan perilaku siswa yang mencerminkan kemampuan siswa terhadap muatan materi IPA yang diukur melalui skor tes kompetensi pengetahuan setelah mengikuti proses pembelajaran yang dilihat dari segi dimensi pengetahuan faktual dan konseptual pada jenjang kemampuan berpikir siswa yaitu mengingat, memahami, menerapkan dan menganalisis pada kelas IV SD Negeri Gugus Letkol Wisnu Kecamatan Denpasar Utara Tahun Ajaran 2017/2018.

Menurut (Susanto, 2013:165) "anggapan sebagian besar siswa yang menyatakan bahwa pelajaran IPA ini sulit adalah benar, terbukti dari hasil perolehan Ujian Akhir Sekolah (UAS) yang dilaporkan oleh Depdiknas masih sangat jauh dari standar yang diharapkan".

Berdasarkan hasil wawancara terhadap wali kelas IV pada tanggal 6 Januari 2018 terhadap kompetensi pengetahuan IPA di Gugus Letkol Wisnu Kecamatan Denpasar Utara, kompetensi pengetahuan IPA yang terjadi di lapangan terdapat kelemahan yang mengakibatkan rendahnya kompetensi pengetahuan IPA. Hal ini disebutkan oleh wali kelas IV di SDN Gugus Letkol Wisnu bahwa 
sejumlah 30\% siswa yang masih mendapatkan nilai dibawah Kriteria Ketuntasan Minimal (KKM) atau siswa yang masih mendapatkan nilai kurang dari 75.

Ada tiga permasalahan yang dapat diidentifikasi sebagai penyebab rendahnya kompetensi pengetahuan IPA siswa berdasarkan wawancara yang dilakukan terhadap guru kelas IV di SD Gugus Letkol Wisnu. Pertama, siswa cenderung menghafal informasi, sehingga otak siswa dipaksa hanya mengingat berbagai informasi tanpa memahami informasi yang diperoleh untuk menghubungkannya dengan situasi dalam kehidupan sehari - hari. Kedua, siswa hanya mendapatkan pengetahuan pada buku teks sebagai satu - satunya sumber belajar. Ketiga, siswa yang cepat bosan dengan pelajaran karena siswa tidak sepenuhnya terlibat secara aktif dan kreatif selama pembelajaran berlangsung.

Sesuai dengan teori Piaget, bahwa usia anak sekolah dasar masih berada di tahap operasional konkret, sehingga kompetensi pengetahuan IPA hendaknya tidak dilakukan secara abstrak, tetapi sedapat mungkin guru menerapkan prinsip-prinsip yang dimulai dari konkret ke abstrak dan tidak lupa memperhatikan hubungan materi pelajaran dengan kehidupan sehari-hari. Selain prinsip - prinsip tersebut, yang harus dimulai dari konkret ke abstrak, hal yang juga harus diperhatikan adalah mengembangkan rasa ingin tahu dan daya berpikir kritis mereka terhadap suatu masalah.

Penggunaan model dan media pembelajaran yang inovatif dapat membuat proses pembelajaran berjalan dengan baik. Selain itu, peranan siswa dapat berpengaruh dalam proses pembelajaran di sekolah, karena siswa dipandang sebagai pusat terjadinya proses pembelajaran yang aktif, mandiri, bertanggung jawab dan berinisiatif untuk mengenal kebutuhan belajarnya, menemukan sumber-sumber informasi untuk menjawab masalah, membangun serta mempresentasikan kemampuannya berdasarkan kebutuhan dan sumber-sumber yang ditemukan atau dengan kata lain, pembelajaran berpusat pada siswa (student centre).

Untuk menunjang proses pembelajaran yang baik maka salah satunya diperlukan model pemebelajaran yang inovatif khususnya dalam kompetensi pengetahuan IPA serta media pembelajaran yang tepat. Model pembelajaran pada dasarnya merupakan bentuk pembelajaran yang tergambar dari awal sampai akhir yang disajikan secara khas oleh guru. Model pembelajaran adalah suatu perencanaan atau suatu pola pembelajaran yang digunakan sebagai pedoman untuk merencanakan pembelajaran di kelas. Media pembelajaran merupakan teknik yang dapat digunakan untuk perantara komunikasi antara guru dan siswa, agar dapat memotivasi siswa untuk belajar.

Pemilihan model pembelajaran dan media pembelajaran juga merupakan salah satu faktor yang dapat mempengaruhi keberhasilan pengetahuan siswa, Dalam memilih model pembelajaran dan media pembelajaran disesuaikan dengan karakteristik yang dimiliki oleh siswa agar proses pembelajaran menjadi efektif.

Berdasarkan permasalahan yang terjadi pada siswa dalam kompetensi pengetahuan IPA yang dipaparkan oleh guru wali kelas IV di SD Gugus Letkol Wisnu, maka peneliti melaksanakan suatu penelitian eksperimen sebagai solusi dalam pemecahan masalah. Penelitian ini dilakukan dengan mengujicobakan model pembelajaran learning cycle 5E berbantuan media lingkungan yang memiliki keunggulan yaitu membuat siswa menjadi lebih aktif dan kreatif dalam pembelajaran, siswa dapat mengungkapkan ide-ide yang dimiliki, mampu menggunakan seluruh kemampuannya serta dapat belajar dalam suasana yang menyenangkan dengan menggunakan media lingkungan. Tidak hanya pembelajaran yang menyenangkan, siswa pun dapat membangun pengetahuannya sendiri melalui model learning cycle $5 \mathrm{E}$ berbantuan media lingkungan, sehingga siswa tidak hanya mengingat pembelajaran namun dapat memahami pembelajaran yang telah dipelajari.

Penggunaan model pembelajaran learning cycle 5E berbantuan media lingkungan memberikan kesempatan kepada siswa mengungkapkan pengetahuan sebelumnya dan kesempatan menyanggah, mendebat gagasan-gagasan mereka. Proses ini dapat mengembangkan tingkat penalaran siswa yang lebih tinggi. Model pembelajaran learning cycle $5 \mathrm{E}$ berbantuan media lingkungan memiliki sintaks yang terdiri dari 5 fase yaitu engagement, exploration, explanation, elaboration, dan evaluation.

\section{METODE PENELITIAN}

Penelitian ini dilaksanakan pada kelas IV SD Negeri di Gugus Letkol Wisnu Kecamatan Denpasar Utara tahun ajaran 2017/2018. Penelitian ini pada dasarnya bertujuan untuk mengetahui perbedaan model pembelajaran learning cycle $5 E$ terhadap kompetensi pengetahuan IPA pada siswa kelas IV di SD Gugus Letkol Wisnu Kecamatan Denpasar Utara Tahun Ajaran 2017/1018. Jenis penelitian ini adalah penelitian eksperimen semu menggunakan desain penelitian Non-Equivalen Control Group Design.

Populasi penelitian ini adalah siswa kelas IV SD Negeri di Gugus Letkol Wisnu Kecamatan Denpasar Utara. Terdapat 7 SD Negeri di Gugus Letkol Winu Kecamatan Denpasar Utara, yaitu SD Negeri 1 Peguyangan, SD Negeri 3 Peguyangan, SD Negeri 5 Peguyangan, SD Negeri 6 Peguyangan, SD Negeri 10 
Peguyangan, SD Negeri 11 Peguyangan dan SD Negeri 12 Peguyangan. Penentuan sampel dilakukan pada penelitian ini adalah dengan teknik random sampling. Berdasarkan hasil random didapatkan 2 kelas sebagai sebagai sampel penelitian, yaitu: kelas IVA SD N 1 Peguyangan sebagai kelompok eksperimen sedangkan kelas IV SDN 12 Peguyangan sebagai kelompok kontrol. Kesetaraan sampel diuji dengan rumus uji-t yakni dengan polled varians. Variabel terikat dalam penelitian ini adalah kompetensi pengetahuan IPA.Variabel bebas dalam penelitian ini adalah model pembelajaran learning cycle $5 e$ berbantuan media lingkungan. Pengumpulan data dalam penelitian ini meliputi data kompetensi pengetahuan IPA. Kegiatan pengumpulan data dilaksanakan pada siswa kelas IV SD di Gugus Letkol Wisnu Kecamatan Denpasar Utara Tahun Ajaran 2017/2018 yang menjadi anggota sampel.

Instrumen yang digunakan untuk mengumpulkan data kompetensi pengetahuan IPA adalah tes objektif dalam bentuk pilihan ganda biasa dengan 4 pilihan jawaban dengan jumlah pertanyaan 50 soal. Menurut Jakni (2016 : 157), "suatu tes dinamakan tes objektif manakala peneliti dapat memberikan skor secara langsung tanpa harus mempertimbangkan jawaban yang diberikan oleh peserta tes". Pada tes pilihan ganda biasanya terdapat bagian kemungkinan jawaban atau alternatif (options). Kemungkinan jawaban (options) terdiri atas satu jawaban yang benar yaitu kunci jawaban dan beberapa pengecoh (distractor).

Tes yang digunakan dalam penelitian ini bersifat terstandar, yaitu tes yang memenuhi kriteriakriteria tertentu seperti kriteria validitas, uji daya beda, indeks kesukaran dan reliabilitas. Berdasarkan perhitungan uji validitas tes hasil belajar pengetahuan IPA, dari 50 butir soal yang diujicobakan kepada 45 responden diperoleh 32 butir soal yang valid dan 18 butir soal yang tidak valid. Uji reliabilitas dilakukan terhadap butir soal yang valid saja, dengan demikian uji reliabilitas bisa dilakukan setelah dilakukan uji validitas. Dari 32 soal yang dinyatakan valid diperoleh $r_{11}=0,83$. Berdasarkan hal tersebut maka $r_{11}>0,70$ artinya bahwa soal tes kompetensi pengetahuan IPA pada penelitian ini tergolong reliable dengan kriteria derajat reliabilitas tinggi.

Analisis data dilakukan untuk menguji hipotesis dalam rangka penarikan kesimpulan. Analisis data yang digunakan dalam penelitian ini adalah uji t. Sebelum dilakukan uji hipotesis terlebih dahulu dilakukan uji prasyarat analisis meliputi uji normalitas dan uji homogenitas. Untuk mengetahui sebaran data skor kompetensi pengetahuan IPA siswa masing-masing kelompok berdistribusi normal atau tidak,

digunakan analisis Chi Kuadrat $\left(X^{2}\right)$ pada taraf signfikansi 5\% dan derajat kebebasan $(\mathrm{dk})=(\mathrm{k}-1)=6-1$

= 5. Kriteria pengujian adalah jika $X_{\text {hitung }}^{2} \leq X_{\text {tabel }}^{2}$ maka data berdistribusi normal. Uji homogenitas varians dilakukan untuk mencari tingkat homogen antara dua kelompok yang diambil yaitu kelompok eksperimen dan kelompok kontrol. Uji homogenitas varians untuk kedua kelompok digunakan uji F.

Dengan kriteria pengujian $F_{\text {hitung }} \leq F_{\text {tabel }}$ maka sampel homogen. Uji dilakukan pada taraf signifikan 5\% dengan derajat kebebasan untuk pembilang $\mathrm{n}_{1}-1$ dan derajat kebebasan untuk penyebut $\mathrm{n}_{2}-1$.

Teknik analisis data yang digunakan untuk menguji hipotesis dalam penelitian ini yaitu menggunakan uji-t dengan rumus polled varians dan $\mathrm{dk}=\mathrm{n} 1+\mathrm{n} 2-2$. Kriteria pengujian ini dengan taraf

signifikansi 5\% yang mengkomparasikan $t_{\text {hitung }}$ dengan $t_{\text {tabel }}$. Apabila $t_{\text {hitung }}>t_{\text {tabel }}$ maka terdapat perbedaan yang signifikan antara kedua variabel atau sampel $\left(\mathrm{H}_{0}\right.$ ditolak).

\section{ANALISIS DAN PEMBAHASAN}

Penelitian ini dilaksanakan pada siswa kelas IV SD Gugus Letkol Wisnu Kecamatan Denpasar Utara Tahun Ajaran 2017/2018. Terdapat dua kelas sebagai sampel penelitian, yaitu kelas IVA SDN 1 Peguyangan yang dibelajarkan dengan model pembelajaran learning cycle $5 \mathrm{E}$ berbantuan media lingkungan sebagai kelompok eksperimen, kelas IV SDN 12 Peguyangan yang dibelajarkan dengan pembelajaran konvensional sebagai kelompok kontrol.

Berdasarkan hasil analisis data, diperoleh nilai rata-rata kelompok eksperimen $=81,53$ dan kelompok kontrol $=72,82$. Ini menunjukkan bahwa nilai rata-rata kelompok eksperimen $=81,53>=$ 72,82 kelompok kontrol. Lebih lanjut, melalui uji hipotesis diperoleh thitung $=4,453$ sedangkan dengan taraf signifikansi $5 \%$ dan $\mathrm{dk}=82$ diperoleh harga ttabel $=1,989$. Dengan demikian, thitung $=4,453>$ ttabel $(\alpha=0,05,82)=1,989$, sehingga hipotesis nol (H0) ditolak. Hasil deskripsi data dapat dilihat pada Tabel 1. 
Tabel 1. Deskripsi Data Nilai Post-test Kompetensi Pengetahuan IPA

\begin{tabular}{lcc}
\hline \multicolumn{1}{c}{ Hasil Analisis } & Kelas Eksperimen & Kelas Kontrol \\
\hline Mean & 81,53 & 72,82 \\
\hline Rerata Persentase & $81,53 \%$ & $72,82 \%$ \\
\hline Standar Deviasi & 8,98 & 8,94 \\
\hline Varian & 80,64 & 79,92 \\
\hline Nilai Maksimum & 97 & 94 \\
\hline Nilai Minimum & 59 & 50 \\
\hline
\end{tabular}

Berdasarkan tabel di atas diketahui bahwa kelompok eksperimen yang dibelajarkan menggunakan model pembelajaran learning cycle $5 E$ berbantuan media lingkungan memiliki nilai rata-rata kompetensi pengetahuan IPA yang lebih tinggi dari kelompok kontrol yang dibelajarkan menggunakan pembelajaran konvensional. Adapun data nilai kompetensi pengetahuan IPA kelompok eksperimen dan kelompok kontrol disajikan dalam diagram batang distribusi frekuensi penguasaan kompetensi pengetahuan IPA yaitu sebagai berikut.

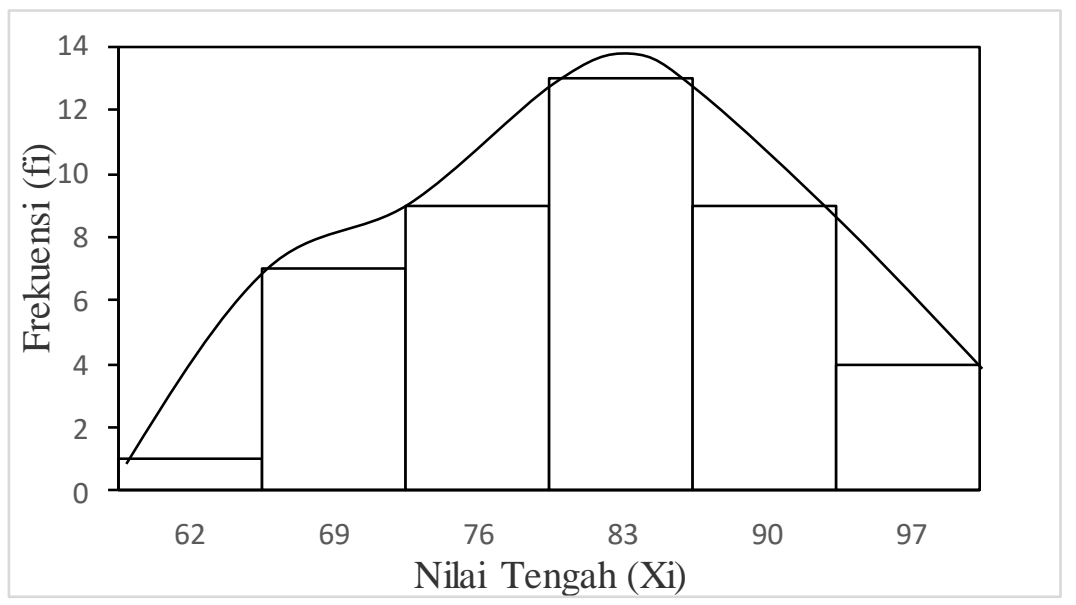

Gambar 1. Histogram Distribusi Frekuensi Kompetensi Pengetahuan IPA Kelompok Eksperimen

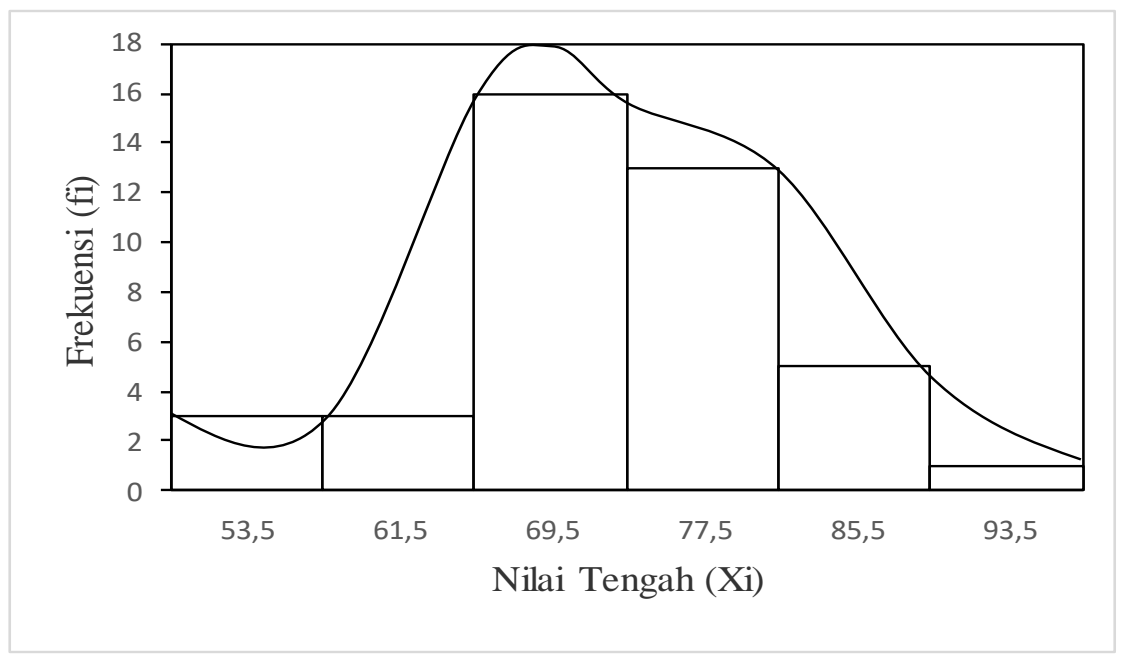

Gambar 2. Histogram Distribusi Frekuensi Kompetensi Pengetahuan IPA Kelompok Kontrol

Data nilai post-test kompetensi pengetahuan IPA pada kelompok eksperimen yaitu siswa kelas IVA SD N 1 Peguyangan yang dibelajarkan melalui model pembelajaran learning cycle 5E berbantuan media lingkungan menunjukkan bahwa skor tertinggi yang dicapai siswa adalah 97 dari skor tertinggi yang 
mungkin dicapai adalah 100, sedangkan skor terendah yang dicapai siswa adalah 59 dari skor yang mungkin dicapai adalah 0, nilai rata-rata yaitu 81,53 dan rata-rata persentase kompetensi pengetahuan IPA kelompok kontrol, M\% 81,53\%

Data nilai post-test kompetensi pengetahuan IPA pada kelompok kontrol yaitu siswa kelas IV SD N 12 Peguyangan yang dibelajarkan melalui pembelajaran konvensional menunjukkan bahwa skor tertinggi yang dicapai siswa adalah 94 dari skor tertinggi yang mungkin dicapai adalah 100, sedangkan skor terendah yang dicapai siswa adalah 54 dari skor yang mungkin dicapai adalah 0, nilai rata-rata yaitu 72,82 dan rata-rata persentase kompetensi pengetahuan IPA kelompok kontrol, M\% 72,82 \%

Hasil uji normalitas kelompok eksperimen, diperoleh Chi Kuadrat hitung ( $\mathrm{x}^{2}$ hitung $\left.=5,14\right)$ kemudian nilai tersebut dibandingkan dengan Chi Kuadrat tabel $\left(\mathrm{x}^{2}\right.$ tabel $\left.=11,07\right)$. Hal ini menunjukkan bahwa $\mathrm{x}^{2}$ hitung $<$ $\mathrm{x}^{2}$ tabel berarti data hasil penguasaan kompetensi pengetahuan IPA kelompok eksperimen berdistribusi normal..

Hasil uji normalitas kelompok kontrol, diperoleh Chi Kuadrat hitung ( $\mathrm{x}^{2}$ hitung $=2,73$ ) kemudian nilai tersebut dibandingkan dengan Chi Kuadrat tabel $\left(\mathrm{x}^{2}\right.$ tabel= 11,07). Hal ini menunjukkan bahwa $\mathrm{x}^{2}$ hitung $<$ $\mathrm{x}^{2}$ tabel berarti data hasil penguasaan kompetensi pengetahuan IPA kelompok kontrol berdistribusi normal.

Homogenitas varians data kompetensi pengetahuan IPA dianalisis dengan uji F Dari hasil analisis, diperoleh $\mathrm{F}_{\text {hitung }}=1,00$ dan $\mathrm{F}_{\text {tabel }}=1,68$. Hal ini berarti $\mathrm{F}_{\text {hitung }}<\mathrm{F}_{\text {tabel }}$, sehingga data kedua kelompok memiliki varians yang homogen.

Hipotesis yang diuji dalam penelitian ini adalah $\mathrm{H}_{0}$ yakni tidak terdapat perbedaan yang signifikan kompetensi pengetahuan IPA antara siswa yang dibelajarkan dengan model pembelajaran learning cycle $5 E$ berbantuan lingkungan dan siswa yang dibelajarkan dengan pembelajaran konvensional pada kelas IV SD Gugus Letkol Wisnu Kecamatan Denpasar Utara Tahun Ajaran 2017/2018.

Kriterian pengujian adalah $\mathrm{H}_{0}$ ditolak jika $t_{\text {hitung }}>\mathrm{t}_{\text {tabel }}$ dimana $\mathrm{t}_{\text {tabel }}$ diperoleh dari tabel distribusi $\mathrm{t}$ pada taraf signifikan $5 \%$ dengan $\mathrm{dk}(\mathrm{n} 1+\mathrm{n} 2)-2$.

Tabel 2. Rangkuman Hasil Uji-t

\begin{tabular}{|c|c|c|c|c|c|c|}
\hline Kelompok & $\mathbf{N}$ & $\mathbf{d k}$ & $\mathbf{X}$ & $\mathbf{S}^{2}$ & $\mathbf{T}_{\text {hitung }}$ & $\mathbf{T}_{\text {tabel }}$ \\
\hline Eksperimen & 43 & & 81,53 & 80,64 & & \\
\hline Kontrol & 41 & 2 & 72,82 & 79,92 & 4,453 & 1,989 \\
\hline
\end{tabular}

Berdasarkan kriteria pengujian karena th $\mathrm{h}_{\text {tung }}>\mathrm{t}_{\text {tabel }}$ maka $\mathrm{H}_{0}$ ditolak. Artinya terdapat perbedaan yang signifikan kompetensi pengetahuan IPA antara kelompok siswa yang dibelajarkan dengan menggunakan model pembelajaran learning cycle $5 E$ berbantuan media lingkungan dan kelompok siswa yang dibelajarkan dengan menggunakan model pembelajaran konvensional pada siswa Kelas IV SD Gugus Letkol Wisnu Kecamatan Denpasar Utara tahun ajaran 2017/2018. Hal ini disebabkan karena model pembelajaran learning cycle $5 E$ merupakan rangkaian tahap-tahap kegiatan yang diorganisasikan sedemikian rupa yang menekankan pentingnya siswa membangun sendiri pengetahuan siswa lewat keterlibatan proses belajar mengajar sehingga siswa dapat menguasai kompetensi-kompetensi yang harus dicapai dalam pembelajaran dengan jalan berperan aktif. Selain itu, model pembelajaran learning cycle $5 E$ berbantuan media lingkungan yang memiliki keunggulan yaitu membuat siswa menjadi lebih aktif dan kreatif dalam pembelajaran, siswa dapat mengungkapkan ide-ide yang dimiliki, mampu menggunakan seluruh kemampuannya serta dapat belajar dalam suasana yang menyenangkan, sehingga pengetahuan yang didapatkan tidak hanya dari buku saja yang sebagai sumber belajar, namun lingkungan sekitar siswa juga bisa dijadikan sebagai sumber belajar.

Pembelajaran learning cycle $5 E$ terdiri dari 5 tahap pembelajaran yang sering disingkat LC 5E (Engagement, Exploration, Explaination, Elaboration, dan Evaluation). Menurut Ngalimun (2017), berikut penjelasan singkat dari 5 tahap dari model pembelajaran learning cycle $5 E$,

"tahap engagement ini minat dan keingintahuan siswa tentang tema yang akan dibelajarkan berusaha dibangkitkan. Hal ini dilakukan dengan cara mengajukan pertanyaan tentang proses faktual dalam kehidupan sehari - hari (yang berkaitan dengan tema yang akan dibelajarkan). Pada tahap exploration, siswa diberi kesempatan untuk bekerja sama dalam kelompok-kelompok kecil tanpa pengajaran langsung dari guru untuk menguji prediksi, melakukan dan mencatat pengamatan serta ideide melalui kegiatan-kegiatan seperti praktikum. Pada tahap exploration, guru hanya berperan sebagai fasilitator dan motivator. Tujuan pada tahap exploration adalah mengecek pengetahuan yang dimiliki siswa apakah sudah benar, masih salah, atau mungkin sebagian salah, sebagaian benar. Pada tahap explanation, guru harus mendorong siswa menjelaskan konsep dengan kalimat mereka sendiri, 
menugaskan siswa untuk memberi bukti dan klarifikasi dari penjelasan mereka, dan mengarahkan kegiatan diskusi. Pada tahap ini siswa menemukan istilah-istilah dari konsep yang dipelajari. Pada tahap elaboration siswa menerapkan konsep dan keterampilan dalam situasi baru melalui kegiatan-kegiatan seperti pratikum. Pada tahap akhir, dilakukan tahap evaluation."

Menurut Ngalimun ( 2017 : 254 ) kelebihan dari model pembelajaran learning cycle 5E adalah, sebagai berikut

"1) meningkatkan motivasi belajar karena siswa dilibatkan secara aktif dalam proses pembelajaran, 2) membantu mengembangkan sikap ilmiah belajar siswa, pembelajaran menjadi lebih bermakna".

Kelebihan dari model pembelajaran learning cycle $5 E$ berbantuan media lingkungan adalah motivasi belajar siswa meningkat karena dapat dilibatkan secara lebih aktif dalam proses pembelajaran, siswa dapat memiliki pengalaman yang lebih riil serta siswa dapat berinteraksi secara langsung dengan benda, lokasi atau peristiwa sesungguhnya secara alamiah.

Penelitian ini diperkuat oleh penelitian yang relevan, yakni berdasarkan penelitian yang dilakukan oleh Arya Kasuma Ditriguna (2013) yang menyatakan bahwa model pembelajaran Siklus Belajar (Learning Cycle) $5 \mathrm{E}$ berpengaruh terhadap sikap ilmiah dan hasil belajar IPA siswa kelas V SDN 5 Pedungan.Hal ini terlihat dari hasil penelitian yang menunjukkan (1) adanya perbedaan yang signifikan sikap ilmiah siswa yang dibelajarkanmelalui model pembelajaran learning cycle $5 E$ diperoleh thitung $=5,72$. Untuk $\alpha=0,05$ dan $d k=82$ diperoleh $t_{\text {tabel }}=2,00$. Berarti $t_{\text {hitung }}=5,72>t_{(0,05,82)}=2,00$. (2) adanya perbedaan yangsignifikan hasil belajar IPA siswa yang dibelajarkan melalui model pembelajaran learning cycle $5 E$ diperoleh $t_{\text {hitung }}=3,49$. Untuk $\alpha=0,05 \mathrm{dan} \mathrm{dk}=82$ diperoleh $\mathrm{t}_{\text {tabel }}=2,00$. Berarti $\mathrm{t}_{\text {hitung }}=3,49>$ $\mathrm{t}_{(0,05,82)}=2,00$. Demikian juga diperkuat oleh penelitian yang dilakukan Zuli Utami (2016) yang menyatakan bahwa model pembelajaran learning cycle $5 E$ berpengaruh terhadap hasil belajar IPA siswa kelas IV SDN Sendangadi 1.Hal ini terlihat dari rata-rata post-test pada kelompok eksperimen yaitu 81,14 lebih dari rata-rata post-test pada kelompok kontrol yaitu 69,23. Selain itu, dengan membandingkan hasil $t_{\text {hitung }}$ dan $t_{\text {tabel }}$ dapat disimpulkan bahwa $t_{\text {hitung }}>t_{\text {tabel }}(4,687>1,99962)$.

\section{KESIMPULAN}

Berdasarkan hasil penelitian dan pembahasan dapat dikemukakan simpulan sebagai berikut. Dari hasil analisis diperoleh nilai rata-rata kompetensi pengetahuan IPA kelas IVA SDN 1 Peguyangan (kelompok eksperimen) $=81,53$ sedangkan kelas IV SDN 12 Peguyangan (kelompok kontrol) $=72,82$. Hal ini menunjukkan bahwa nilai rata-rata kompetensi pengetahuan IPA antara siswa yang belajar dengan menggunakan model pembelajaran learning cycle $5 \mathrm{E}$ berbantuan media lingkungan lebih besar daripada siswa yang belajar dengan pembelajaran konvensioanal pada siswa kelas IV SD Gugus Letkol Wisnu Kecamatan Denpasar Utara

Dari pengujian hipotesis dengan uji-t diperoleh nilai thitung $=4,453$ sementara ttabel pada taraf signifikansi $5 \%$ dan $\mathrm{dk}=82=1,989$. Hal ini berarti bahwa thitung $>$ ttabel, sehingga H0 ditolak. Hal ini berarti terdapat perbedaan yang signifikan kompetensi pengetahuan IPA antara kelompok siswa yang dibelajarkan dengan menggunakan model pembelajaran learning cycle $5 \mathrm{E}$ berbantuan media lingkungan dan kelompok siswa yang dibelajarkan dengan menggunakan model pembelajaran konvensional pada siswa kelas IV SD Gugus Letkol Wisnu Kecamatan Denpasar Utara tahun ajaran 2017/2018.Berdasarkan perbedaan nilai rata-rata kedua kelompok dan hasil uji hipotesis, maka dapat disimpulkan bahwa penerapan model pembelajaran learning cycle $5 \mathrm{E}$ berbantuan media lingkungan berpengaruh terhadap kompetensi pengetahuan IPA siswa kelas IV SD Gugus Letkol Wisnu Kecamatan Denpasar Utara Tahun Ajaran 2017/2018.

Atas dasar simpulan penelitian tersebut, diajukan beberapa saran sebagai berikut. 1) kepada guru disarankan dapat menerapkan inovasi-inovasi baru dalam merancang suatu pembelajaran untuk dapat memotivasi dan memfasilitasi potensi yang dimiliki oleh siswa sehingga dapat mencapai hasil belajar yang optimal. Inovasi pembelajaran dapat berupa penggunaan model pembelajaran serta media pembelajaran yang inovatif. 2) kepada siswa disarankan dapat lebih aktif dalam kegiatan pembelajaran, dan pembelajaran IPA menjadi lebih menarik dan bermakna dengan diterapkannya model pembelajaran learning cycle $5 \mathrm{E}$ berbantuan media lingkungan.3) disarankan sekolah melaksanakan sosialisasi secara berkelanjutan mengenai inovasi-inovasi pembelajaran kepada guru-guru dalam membelajarkan siswa dengan tujuan perubahan paradigma proses pembelajaran di sekolah yang menunjang kredibelitas menjadi sekolah yang unggul dan inovatif. 4) bagi peneliti lain disarankan dapat melakukan penelitian menggunakan model pembelajaran learning cycle 5E berbantuan media lingkungan yang digunakan sebagai referensi untuk melaksanakan penelitian selanjutnya atau bisa menemukan inovasi kegiatan pembelajaran lainnya yang bermakna dan menyenangkan bagi siswa. 


\section{DAFTAR PUSTAKA}

Asthira P, I Wy., Nym. Kusmariyatni, I Gd. Margunayasa. 2016. Pengaruh Model Pembelajaran Learning Cycle "5e" Terhadap Hasil Belajar Ipa Siswa Kelas V Di Gugus III. e-Journal PGSD Universitas Pendidikan Ganesha Jurusan PGSD Vol: 4 No: 1.

Darmadi, Hamid. 2013. Metode Penelitian Pendidikan. Bandung: Alfabeta.

Hamalik, Oemar. 2013.Kurikulum dan Pembelajaran.Jakarta:Bumi Aksara.

Jakni. 2016. Metodologi Penelitian Eksperimen Bidang Pendidikan. Bandung:Alfabeta.

Kemendikbud. 2014. Permendikbud Nomor 57 Tahun 2014. Jakarta: Kementerian Pendidikan dan Kebudayaan.

Kemendikbud. 2014. Permendikbud Nomor 103 Tahun 2014. Jakarta: Kementerian Pendidikan dan Kebudayaan.

Kosasih. 2014. Strategi Belajar dan Pembelajaran.Bandung : Yrama Widya.

Latifa, Baiq Rizkia Ayu, Ni Nyoman Sri Putu Verawati, Ahmad Harjono. 2017. Pengaruh Model Learning Cycle 5e (Engage, Explore, Explain, Elaboration, \& Evaluate) Terhadap Kemampuan Berpikir Kritis Peserta Didik Kelas X Man 1 Mataram. Jurnal Pendidikan Fisika dan Teknologi Volume III No 1.

Ngalimun. 2017. Strategi dan Model Pembelajaran. Yogyakarta: Aswaja Pressindo.

Novianti, Aryani, Meiry Fadilah Noor, Baiq Hana Susanti. 2014. Pengaruh Model Pembelajaran Learning Cycle Terhadap Keterampilan Berpikir Kritis Siswa. EDUSAINS. Volume VI Nomor 01 Tahun 2014, 110 - 116

Pramawati, Liza. 2012. Penerapan Model Pembelajaran (Learning Cycle) Untuk Meningkatkan Keterampilan Proses Dan Hasil Belajar Sains Siswa Kelas VII5 SMP Kartika 1-5 Pekanbaru Tahun Ajaran 2011/2012. Jurnal Online Pdf (Diakses tanggal 2 April 2018).

Shoimin, Aris. 2014. 68 Model Pembelajaran Inovatif dalam Kurikulum 2013. Yogyakarta:AR-Ruzz Media.

Simatupang, Dorlince. 2008. Pembelajaran Model Siklus Belajar (Leraning Cycle). Jurnal $\begin{array}{lllll}\text { Kewarganegaraan, } & \text { (online), } & 10 & \text { (1): } & 62-70\end{array}$ (http://isjd.pdii.lipi.go.id/admin/jurnal/101086270_1693-7287.pdf), diakses tanggal 15 Januari 2018.

Sugiantara, I Pt, Nym Kusmariyatni, I Gd Margunayasa. 2013. Pengaruh Model Pembelajaran Learning Cycle 5e Terhadap Hasil Belajar Ipa Siswa Kelas V Di Gugus Vii Kecamatan Buleleng. E-journal Mimbar PGSD Universitas Pendidikan Ganesha Vol 1, No 1

Susanto, Ahmad. 2013. Teori Belajar dan Pembelajaran di Sekolah Dasar. Jakarta: Kencana.

Utami, Zuli. 2016.Pengaruh Learning Cycle 5e Terhadap Hasil Belajar Ipa Siswa Kelas Iv Sdn Sendangadi 1. Jurnal Pendidikan Guru Sekolah Dasar Edisi 3 Tahun ke-5.

Wisudawati, Asih Widi dan Eka Sulistyowati. 2015. Metodologi Pembelajaran IPA. Jakarta: Bumi Aksara. 